\title{
Editorial: Immigrant and Ethnic Entrepreneurship
}

The importance of businesses started and developed by immigrants is host countries is substantial. Just in the US, 90 of the enterprises listed on Fortune 500 have been founded by immigrants (cf. Partnership for a New American Economy, 2011). As the contribution of immigrant entrepreneurship for the global economy is recognized by policy makers and experts, it is also reflected in the growing research on this topic. Research papers on immigrant and ethnic entrepreneurship have increased in numbers in 2000s and in the second decade of 21st century (Drori, Honig, \& Wright, 2009; Mueller, 2014; AliagaIsla \& Rialp, 2013).

Still, this emerging and rapidly growing field of study suffers from a number of limitations. The first one is the concentration of the bulk of the research on a small number of countries (mostly the US and Canada) and few, selected ethnic groups (Latino, Chinese, Korean). The second deficiency is the modest number of theoretical concepts developed for the analysis of the phenomenon. Another gap in the current research is the small number of quantitative approaches. Then, there are several underserved topics, including less popular geographical locations, disadvantaged immigrant ethnic groups at the risk of marginalization on one hand, and the successful intentional immigrant entrepreneurs on the other, and the gender perspective. Finally, the most visible drawback in current research agenda is the limited interdisciplinary approach both to empirics and theory. Although immigrant entrepreneurship research is firmly established within the business/entrepreneurship studies, it needs a more comprehensive dialogue with the migration studies, including such disciplines as sociology and anthropology.

Our special issue on immigrant and ethnic entrepreneurship aims to address at least some of the aforementioned research gaps. The first paper Economic Integration of Immigrant Entrepreneurs authored by Nonna Kushnirovich depicts the topic from the perspective of an important, yet seldom mentioned in former studies, country - Israel. This empirical paper uses a quantitative approach, and the novelty is the comparative analysis of the economic performance of the immigrant entrepreneurs with the native-born entrepreneurs.

The second paper Immigrant Capital and Entrepreneurial Opportunities written by Malavika Sundararajan and Binod Sundararajan offers a new and extremely stimulating theoretical perspective for the studies of immigrant businesses. The authors develop a concept of immigrant capital and posit prepositions that can be tested in the future empirical research projects.

Beata Glinka and Agnieszka Brzozowska enrich the interdisciplinary dimension of the immigrant entrepreneurship research. In their paper entitled Immigrant Entrepreneurs: in Search of Identity they analyse the seldom inspected issue of ethnic identity dynamics 
of the business owners in a host country, connecting this field of research to migration studies literature.

Prue Cruickshank and Ann Dupuis investigate the process of economic adaptation of immigrant entrepreneurs from the perspective of New Zealand. In their article entitled The Adaptation of Intentional Immigrant Entrepreneurs: A Case Study, they focus on a very specific, and not widely explored, type of immigrant entrepreneurs - the intentional investors, who come to a host country with a specific aim to set up a business, attracted by specific migration programs. Therefore, their analysis is very interesting from the perspective of policy-makers.

Sharon Doreen Mayer, Aki Harima and Jörg Freiling in their paper Network Benefits for Ghanaian Diaspora and Returnee Entrepreneurs analyse the importance of networks by diaspora and returnee entrepreneurs. Their paper, albeit explorative in nature, offers a fresh perspective on the investigations on the role of social capital for the migrant business development.

Sylvie Pare and Ralph Christian Maloumby-Baka in the article The Role of 'Public Third Sector' Relations in Solving Social Issues: the Case of the One-Stop-Shop Service for the Promotion of Female Immigrant Entrepreneurship in Montreal focus on the linkages between the public and third sector, and the immigrant economic integration and immigrant entrepreneurship of the disadvantaged social groups, namely the females. Thus, the paper provides a valuable contribution by introducing a gender perspective to the topic of immigrant businesses.

The final paper Modes of Entry to Male Immigrant Entrepreneurship in a Rural Context: Start-up Stories from Northern Norway authored Mai Camilla Munkejord, corresponds to the former one, by also adapting the gender perspective lens. Additionally, this research investigates a very specific type of entrepreneurship, started and developed by immigrants in rural areas, which is an additional novelty.

I hope that both scholars and policy-makers will find this issue interesting and stimulating.

Jan Brzozowski Issue Editor

\section{REFERENCES}

Aliaga-Isla, R., \& Rialp, A. (2013). Systematic Review of Immigrant Entrepreneurship Literature: Previous Findings and Ways Forward. Entrepreneurship \& Regional Development, 25(9-10): 819-844.

Drori, I., Honig, B., \& Wright, M. (2009). Transnational Entrepreneurship: An Emergent Field of Study. Entrepreneurship Theory and Practice, 33(5), 1001-1022.

Mueller, E. (2014). Entrepreneurs from Low-skilled Immigrant Groups in Knowledge-intensive Industries: Company Characteristics, Survival and Innovative Performance. Small Business Economics, 42(4), 871-889.

Partnership for a New American Economy (2011). The "New American" Fortune 500. Partnership for a New American Economy, June 2011. 